2011-10-02

\title{
Domestic Application of Micro Wind Turbines in Ireland: Investigation of Their Economic Viability
}

Zhe Li

Technological University Dublin, zhe.li@tudublin.ie

Fergal Boyle

fergal.boyle@tudublin.ie

Anthony Reynolds

anthony.reynolds@tudublin.ie

Follow this and additional works at: https://arrow.tudublin.ie/engschmecart

Part of the Engineering Commons

\section{Recommended Citation}

Li, Z., Boyle, F., Reynolds, A.:Domestic Application of Micro Wind Turbines in Ireland: Investigation of Their Economic Viability. Renewable Energy, 2011. doi:10.1016/j.renene.2011.10.001

This Article is brought to you for free and open access by the School of Mechanical and Design Engineering at ARROW@TU Dublin. It has been accepted for inclusion in Articles by an authorized administrator of ARROW@TU Dublin. For more information, please contact arrow.admin@tudublin.ie, aisling.coyne@tudublin.ie, gerard.connolly@tudublin.ie.

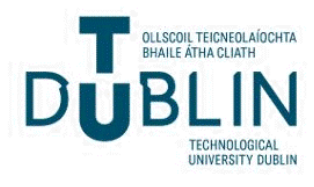




\title{
Domestic application of micro wind turbines in Ireland: Investigation of their economic viability
}

\author{
Zhe Li*, Fergal Boyle, Anthony Reynolds \\ Department of Mechanical Engineering, Dublin Institute of Technology, Bolton Street, Dublin 1, Ireland
}

\section{A R T I C L E I N F O}

Article history:

Received 22 December 2010

Accepted 2 October 2011

Available online $\mathrm{xxx}$

\section{Keywords:}

Renewable energy

Wind energy

Micro wind turbine

Economic viability

Sustainable living

Ireland

\begin{abstract}
A B S T R A C T
Electricity generation from renewable sources of energy will be a key part in the development of future strategies for many countries globally. This renewable electricity generation will be hugely important for Ireland, due to its lack of fossil fuel resources. The extremely good wind resource available provides Ireland with the opportunity of generating vast amount of electricity from wind energy. Large-scale wind electricity generation reached $1264 \mathrm{MW}$ installed capacity by January 2010 in Ireland. However, micro scale wind electricity generation has not been very popular in Ireland to-date. The unclear economics of micro wind turbines, under Irish conditions, is considered the biggest obstacle for expanding micro wind turbine installation in Ireland. This paper presents a methodology to accurately evaluate the economic viability of a micro wind turbine on a case-by-case basis. The methodology utilises the software programmes HOMER and Microsoft Excel 2007 for the energy and economic analyses. This paper also presents a realistic economic analysis of a number of micro wind turbines available in Ireland.
\end{abstract}

(c) 2011 Elsevier Ltd. All rights reserved.

\section{Introduction}

Renewable sources of energy have shown their growing importance in power generation in recent years worldwide. The utilisation of renewable sources of energy is even more important for Ireland due to its lack of fossil fuel resources. Peat is the only indigenous fossil fuel available in Ireland. Electricity is mainly generated from imported natural gas and coal.

In contrast to the lack of fossil fuels available, Ireland has an abundance of renewable energy resources, and wind energy in particular. The wind energy resource in Ireland is four times that of the European average [1]. This exceptionally good wind resource offers Ireland a huge potential for electricity generation by wind energy. The electricity generated from large-scale wind turbines had reached 1264 MW installed capacity by January 2010 in Ireland [2]. In comparison to the ever-growing large-scale wind-electricity generation, micro-scale wind-electricity generation has not yet fulfilled its potential in Ireland. Householders and the country could both benefit from micro wind-electricity generation. Ideally, householders may get a few years of free electricity supply from installed micro wind turbines. From the country's point of view, the pressure on electricity supply will be eased and the greenhouse gases emitted will be reduced.

\footnotetext{
* Corresponding author. Tel.: +353 (0) 14022991.

E-mail addresses: zhe.li@dit.ie, zhe.li_bruce@hotmail.com (Z. Li).
}

The unclear economics of micro wind turbines remains the biggest obstacle for expanding micro wind turbine installation in Ireland. There is a complex interplay of technical, economic and climate factors, which must be evaluated on a case-by-case basis, and with the rapid rate of current technical development, as well as significant changes in government policies, the situation is a dynamically changing one [3]. This paper presents a methodology for calculating the economics of a micro wind turbine. Using this methodology, this paper accurately establishes the economical viability of a number of grid-connected micro wind turbines in Ireland. The study also demonstrates the change in economical viability of these micro wind turbines when realistic assumptions are made. This methodology may also be applied for examining the economical viability of other micro wind turbines which this paper has not mentioned.

\section{The household electricity situation in Ireland}

The average annual electricity consumption load for a house in Ireland was $5557 \mathrm{kWh}$ in 2008 [4]. Household electricity consumption has increased with an average annual growth rate of $4.1 \%$ from 1990 to 2008 . This increased electricity consumption was mainly due to a doubling of the average number of household electrical appliances during that period and the increased use of these appliances. The average house is also responsible for approximately 3.2 tonnes of greenhouse gas emissions per year [5]. 


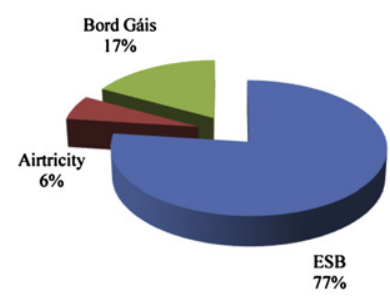

December 2009

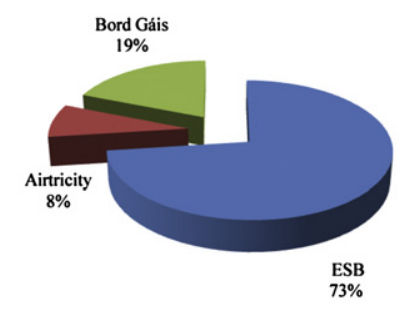

March 2010

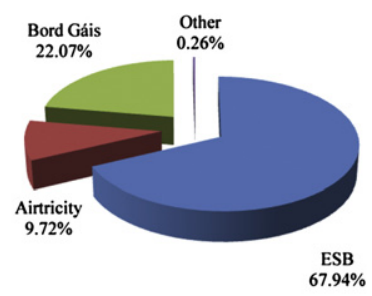

June 2010

Fig. 1. Household electricity supplier market share (GWh) in Ireland in December 2009, March 2010 and June 2010 [6].

There are three main electricity suppliers to households in Ireland: the Electricity Supply Board (ESB), Airtricity and Bord Gáis. The ESB was established in 1927 and is a state body that is owned and controlled by the Irish government. The ESB was the dominant electricity supplier to households until the electricity market opened to competition in Ireland on the 19th of February 2005. Since then, Airtricity has re-entered and Bord Gáis has entered the electricity supply market and are competing for business. Householders have been freely able to switch from one electricity supplier to another electricity supplier. The Commission for Energy Regulation, the regulator for the electricity and natural gas sectors in Ireland, has not allowed the ESB to change its price, so that the other suppliers can gain some market share. This will change however once the ESB market share reaches 60\%. The switch rate from the ESB to the other electricity suppliers was initially low. The market, however, has been experiencing a high rate of switching from early 2009 to the end of June 2010. As a result, the ESB has seen a significant reduction in its share of the domestic electricity supply market since early 2009. However, the ESB still retained approximately $68 \%$ of the market in mid 2010 [6]. Fig. 1 shows the domestic electricity supplier market share in Ireland from December 2009 to June 2010.

Household imported electricity prices have lowered since 2007. The current imported electricity tariffs (including VAT at the rate of $13.5 \%$ ) from the ESB is $€ 0.16 / \mathrm{kWh}$ in 2010 . However, the electricity costs to householders in Ireland are still one of the highest in Europe. The electricity price in Ireland (including all taxes) was on average $6.6 \%$ higher than the average of the EU-27 countries in 2009 and was ranked the seventh most expensive [7]. Fig. 2 shows the electricity price to domestic consumers in Ireland compared with other EU members in 2009.

Ireland's national electricity grid is developed by ESB Networks and operated by EirGrid. ESB Networks was established in 2001 and is currently responsible for building, maintaining and developing

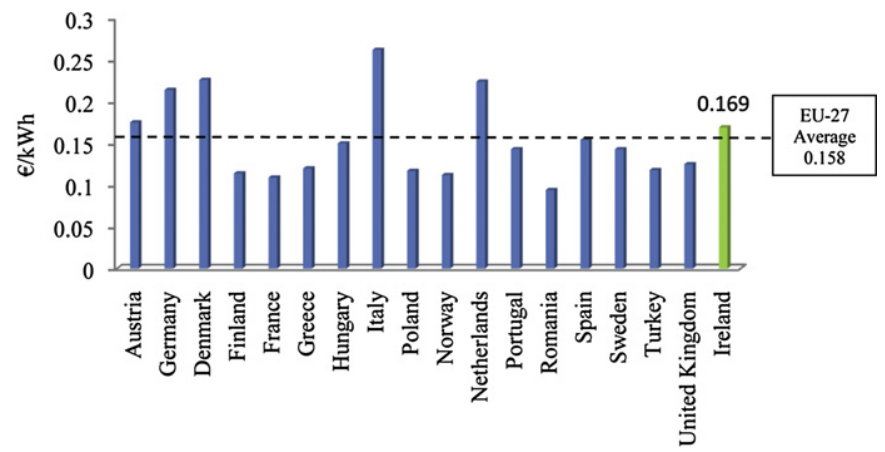

Fig. 2. Domestic electricity prices (including all taxes) in selected EU-27 countries in 2009 [7]. the electricity network and serving all electricity customers in Ireland, irrespective of their supplier. EirGrid is currently responsible for operating the network of high voltage transmission lines and substations to transport power from the various electricity generators to locations where it is needed around the country. There is a legal agreement in place between ESB Networks and EirGrid that sets down the terms under which ESB Networks provides infrastructure services to EirGrid.

\section{The current micro wind turbine situation in Ireland}

The overall micro wind turbine situation in Ireland is best described under four heading: the current micro wind turbine market, the micro wind turbines available on the Irish market, the current legislation and regulations for installing a micro wind turbine, and the current financial support for exporting electricity generated from micro wind turbines. These are described below.

\subsection{The current micro wind turbine market}

Micro renewable electricity generation has not been very popular in Ireland to-date. However, a micro wind turbine is far more popular than any other type of device for micro renewable electricity generation in Ireland. As shown in Fig. 3, 579 micro wind turbines have been registered with the ESB and been connected to ESB Networks (grid) from January 2007 to February 2010 [8]. This accounted for $84 \%$ of all grid-connected micro renewable electricity generation devices in this period [8]. However, the total number of installed micro wind turbines is certain to be higher, as a small number of micro wind turbines are either used to connect with batteries or are waiting to connect to ESB Networks. Micro wind turbines have not yet become an attractive renewable energy technology in electricity generation for households, even though there is an abundance of wind resource in Ireland. There are a few major factors that may affect householders' decision on purchasing

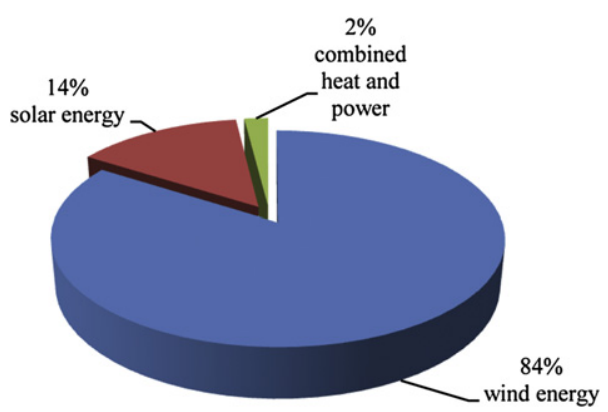

Fig. 3. Breakdown of grid-connected micro renewable electricity generation devices installed from January 2007 to February 2010 in Ireland [8]. 
a micro wind turbine, including the cost of a micro wind turbine, the loan rate from a bank or a credit union, the government grant available, the imported electricity price and the exported electricity price.

\subsection{Micro wind turbines available on the Irish market}

The microgeneration certification scheme is an independent scheme that certifies microgeneration products and installers for Ireland and the UK in accordance with consistent standards. There is a list available from this scheme of registered micro wind turbines. All of these registered wind turbines are available on the Irish market. These turbines are reliable and can be readily purchased from suppliers in Ireland and the UK, e.g. the Proven 11, the Skystream 3.7 and the Swift 1.5 kW. These are shown in Fig. 4. The wide range of wind turbines available should be sufficient to satisfy householders' needs under individual circumstances, i.e. location, wind speed and household electrical load required.

\subsection{The current legislation and regulations for installing a micro wind turbine in Ireland}

Installing a domestic micro wind turbine in Ireland is usually subject to planning permission. However, the installation of a domestic micro wind turbine may be exempt from planning permission if it is installed under certain conditions. These conditions for exemption from planning permission are clearly stated in the Irish government report Planning and Development Regulations 2007 produced by the Department of Environment, Heritage and Local Government in January 2007. These conditions are [14]:
- The turbine shall not be erected on, or attached to, the house or any building or other structure within its curtilage.

- The total height of the turbine shall not exceed $13 \mathrm{~m}$.

- The rotor diameter shall not exceed $6 \mathrm{~m}$.

- The minimum clearance between the lower tip of the rotor and ground level shall not be less than $3 \mathrm{~m}$.

- The supporting tower shall be a distance of not less than the total structure height (including the blade of the turbine at the highest point of its arc) plus $1 \mathrm{~m}$ from any party boundary.

- Noise levels must not exceed $43 \mathrm{db}(\mathrm{A})$ during normal operation, or in excess of $5 \mathrm{db}(\mathrm{A})$ above the background noise, whichever is greater, as measured from the nearest neighbouring inhabited dwelling.

- No more than one turbine shall be erected within the curtilage of a house.

- No such structure shall be constructed, erected or placed forward of the front wall of a house.

- All turbine components shall have a matt non-reflective finish and the blades shall be made of material that does not deflect telecommunication signals.

- No sign, advertisement or object not required for the functioning or safety of the turbine shall be attached to, or exhibited on, the wind turbine.

If the installation of a domestic micro wind turbine does not satisfy these conditions, it must undergo the planning process, and permission may still be given, especially if the turbine does not meet the height requirement only. A roof-top-mounted wind turbine does not qualify for exemption from planning permission; it must be considered on a case by case basis.

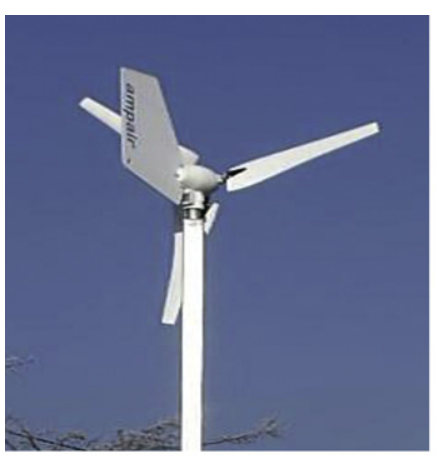

Ampair 600-230[9]

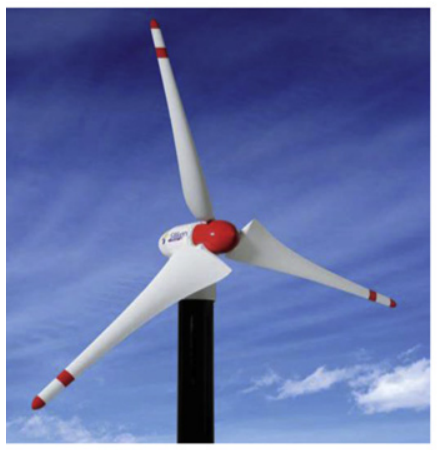

Siliken 3.4[12]

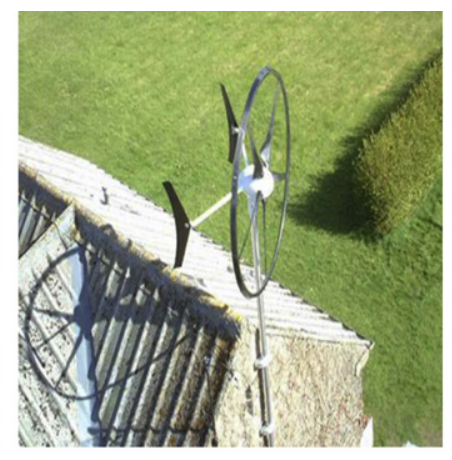

Swift $1.5 \mathrm{~kW}[10]$

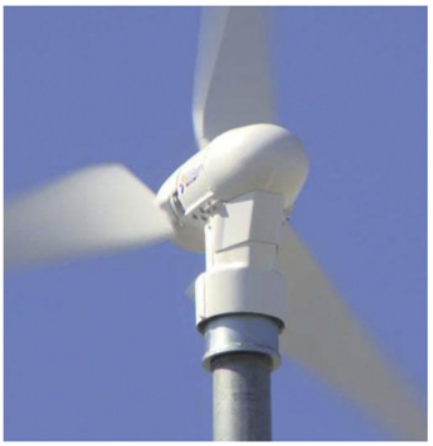

Siliken 4.1[12]

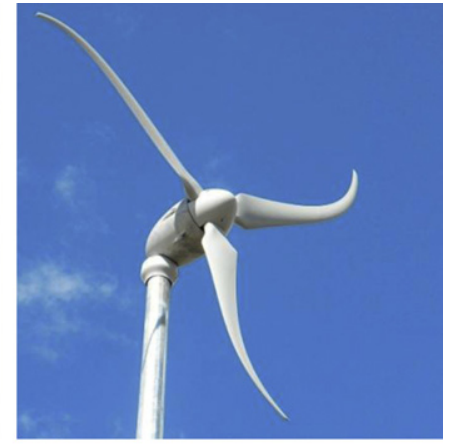

Skystream 3.7[11]

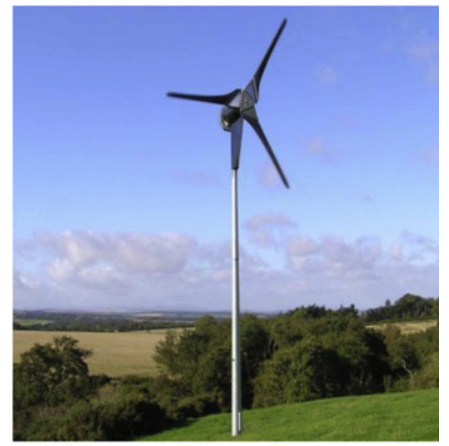

Proven 11[13]

Fig. 4. Six micro wind turbines available on the Irish market in 2010 [9-13]. 
In order to protect the grid, the maximum rated power output from a grid-connected micro wind turbine is subjected to a limit. The limit is $6 \mathrm{~kW}$ when the connection is single phase and $11 \mathrm{~kW}$ when the connection is three phase [15]. A micro wind turbine which does not comply with these limitations will not be allowed to connect to ESB Networks as it may cause grid disruption.

\subsection{The current financial support for exporting electricity generated from micro wind turbines}

In general, $€ 0.09$ is paid by ESB Customer Supply to the householder for every kWh electricity exported to ESB Networks from a micro electricity generation device in Ireland. This price is a standard payment tariff and there is no restriction on the amount of electricity sold. There is an incentive payment tariff supplied by the ESB in order to encourage householders to utilise micro renewable generation. A supplementary payment of $€ 0.10$ is added on for every kWh of exported electricity, but is capped at $3000 \mathrm{kWh}$ per annum and applies for a maximum of five years from the start of the contract. This contract is signed with ESB Customer Supply and allows householders to generate electricity for their own use and export any excess through an import/export meter to ESB Networks [15].

\section{The methodology for economic viability analysis for micro wind turbines in Ireland}

The methodology for analysing the economic viability of micro wind turbines consists of four steps and is implemented in HOMER and Microsoft Excel 2007:

1) Generation of the hourly household electrical load (either Microsoft Excel 2007 or HOMER).

2) Generation of the hourly wind speed (HOMER).

3) Determination of the hourly power output from the micro wind turbine (HOMER).

4) Calculation of the payback period (Microsoft Excel 2007).

HOMER (Hybrid Optimisation Model for Electric Renewables) version 2.76 is a simulation and optimisation software tool. HOMER is developed by the US National Renewable Energy Laboratory (NREL) [16]. It contains a number of renewable energy component models and evaluates suitable technologies options based on the cost and availability of resources [17]. The information on resources, control methods and constraints as well as inputs on component types, numbers, costs, efficiency and longevity is required before performing a simulation over a full year and an analysis by HOMER. The sensitivity analysis can replace a specific number by variables having a range of values. This could allow one to determine the effects of change in a certain parameter on the overall system.

\subsection{Generation of the hourly household electrical load}

In the methodology the hourly household electrical load is required. However, the exact hourly household electrical load over a complete year is very seldom available. Therefore, a procedure is established to generate the hourly household electrical load. This procedure, implemented in Microsoft Excel 2007, requires two pieces of information:

- An average annual household electrical load. The annual electrical load for an average house in Ireland was $5557 \mathrm{kWh}$ in 2008 [18].

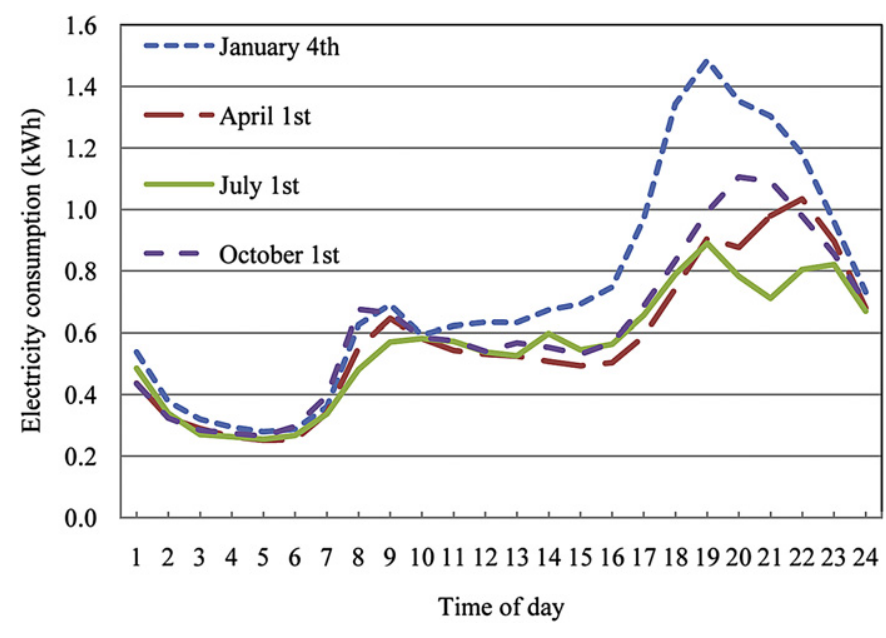

Fig. 5. Examples of generated hourly electrical loads for four days in Ireland.

- An average annualised electrical load profile (ratio of hourly to yearly electricity consumption). An average annualised electrical load profile provided by ESB Networks is used to account for seasonal factors and it represents the closest to realistic house electricity consumption in Ireland [19]. Generally, on average, electricity consumption is significantly higher in winter than summer due to heating requirements and additional lighting [3].

The 8760 hourly household electricity load values, in kWh, can be worked out by using the average annual household electricity load and the average annualised electrical load profile in a complete year for an average house in Ireland. Examples of generated daily household electricity load profiles are shown in Fig. 5.

Alternatively, hour-by-hour household electrical loads can be artificially generated by HOMER. An hourly electrical load profile for one day (one set) in a year is the minimum requirement. Then, HOMER is capable of synthesizing 8760 hourly electrical load values for an entire year by using this hourly electrical load profile and adding random variability parameters (day-to-day, time stepto-time step). HOMER is able to take a maximum of 24 sets of hourly electrical load values consisting of two sets of values for a weekday and a weekend for each month from January to

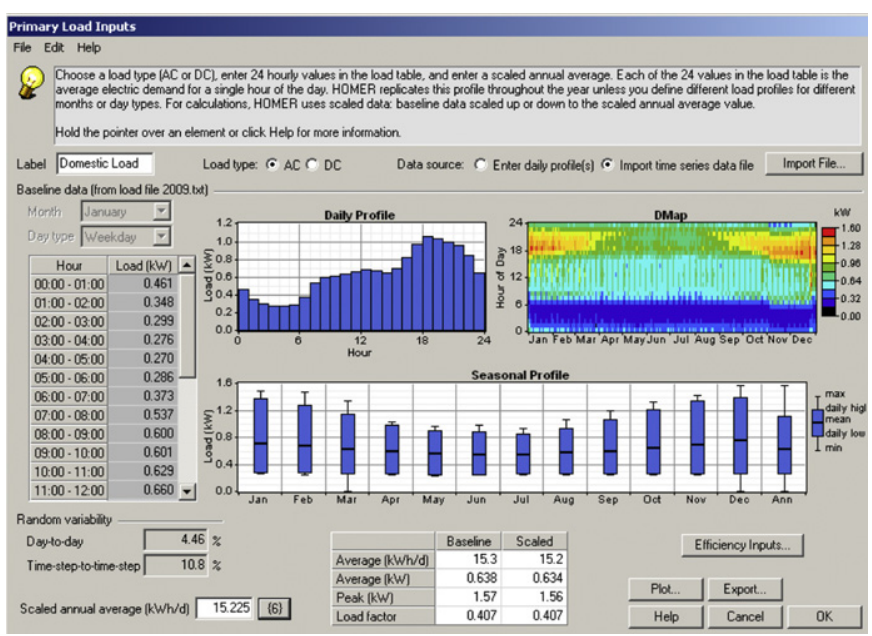

Fig. 6. The HOMER display for generating the hourly household electrical load. 


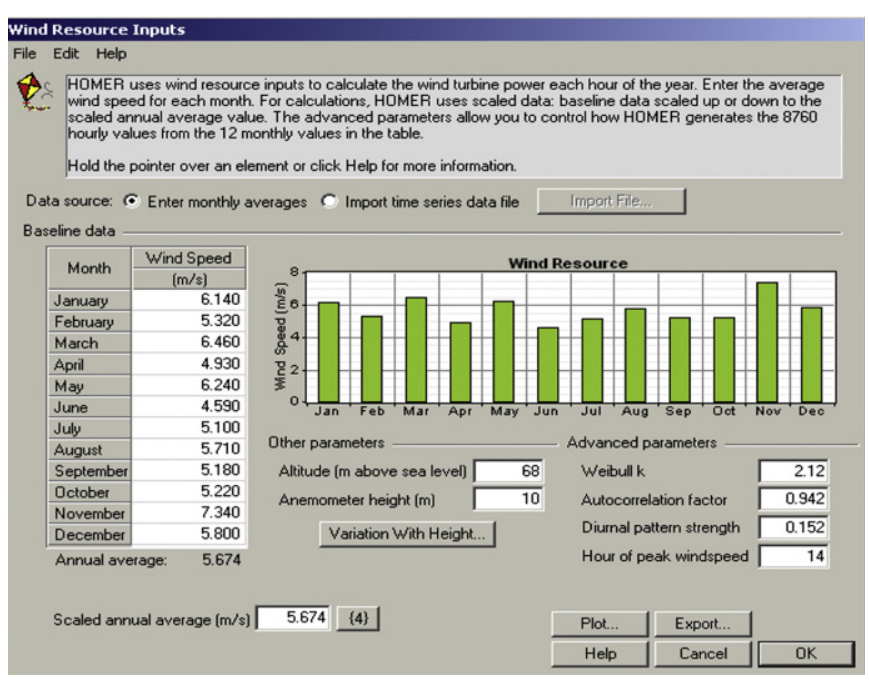

Fig. 7. The HOMER display for generating the hourly wind speed data at Dublin airport.

December. In this case, the seasonal variation can be seen from the generated 8760 hourly electrical load values. However, there is no recognition of any special events, e.g. holiday periods (Christmas, Easter), bank holidays and summer holidays. Fig. 6 shows the HOMER display for generating the hourly household electrical load.

\subsection{Generation of hourly wind speed}

The hourly wind speed data for an entire year at many locations are usually unavailable or too expensive to purchase. In order to achieve best accuracy, artificial but statistically reasonable hourly wind speed data can be generated using HOMER's synthetic wind speed data synthesis algorithm. This algorithm can produce data that mimic the characteristics of real wind speed, including strong and sustained gusts, long lulls between windy periods, and seasonal and diurnal patterns.

In this methodology, the monthly average wind speed at the turbine height for a year at the location at which the turbine is to be installed is required. If the monthly average wind speed is not available, the annual average wind speed is used (for each month); the use of an annual average wind speed shows no realistic seasonal variation however. A logarithmic wind velocity profile is used for calculating the wind speed at the micro wind turbine hub height if the turbine hub height differs from the height at which the measurements are taken. This accounts for the fact that wind speed tends to increase with height above ground, as the effect of obstacles (buildings and vegetation) decreases with height. A logarithmic wind velocity profile uses a surface roughness coefficient length in its calculation. The surface roughness coefficient length is to characterise the landscape condition; in this research a value 0.1 is used to represent a landscape condition of an open field.

The hourly wind speed data is generated by performing complex statistical calculations. Fig. 7 shows the HOMER display for generating the hourly wind speed data at Dublin airport. The calculation is based on the average monthly wind speed data at the micro wind turbine hub height and adding four random variability parameters. These four parameters can accurately reflect the wind condition for a particular location ensuring the most realistic hourly wind speed data are generated. The four parameters are: Weibull $\mathrm{k}$ factor, autocorrelation factor, diurnal pattern strength and hour of peak wind speed. These are described below.

- Weibull $\mathrm{k}$ factor reflects the breadth of a distribution of wind speeds in the Weibull distribution. The Weibull distribution is a two-parameter function that is commonly used to fit the wind speed frequency distribution [20]. A value of 2.12 was calculated in this research to represent Irish conditions.

- Autocorrelation factor is the degree of dependence on preceding values and is a measure of how strongly the wind speed in one hour depends on the wind speeds in previous hours. A value of 0.942 was calculated in this research to represent Irish conditions.

- Diurnal pattern strength reflects how strongly the wind speeds depends on the time of a day. A value of 0.152 was calculated in this research to represent Irish conditions.

- Hour of peak wind speed is the hour of the day that tends to be the windiest, on average. The windiest time appears to be 14:00 in Ireland and this value is utilised in this study.

Table 1

Validation of the wind speed algorithm using the Wilcoxon Rank-Sum Test.

Denoting the mean monthly power output obtained from measured hourly wind speeds by $\mu 1$ and the mean monthly power output obtained from generated hourly wind speeds by $\mu 2$.

\begin{tabular}{|c|c|c|c|c|c|}
\hline \multicolumn{2}{|l|}{ Test the hypothesis, $\mathrm{H}_{0}: \mu 1=\mu 2$} & \multicolumn{4}{|c|}{ Against the alternative, $\mathrm{H}_{1}: \mu 1 \neq \mu 2$} \\
\hline $\begin{array}{l}\text { Monthly power output (kWh) } \\
\text { obtained from measured hourly } \\
\text { wind speeds }\end{array}$ & $\begin{array}{l}\text { Monthly power output (kWh) } \\
\text { obtained from generated hourly } \\
\text { wind speeds }\end{array}$ & \multicolumn{4}{|c|}{ Ranking of monthly power outputs } \\
\hline 1297 & 1204 & 584 & 1 & 1054 & 13 \\
\hline 660 & 584 & 648 & 2 & 1106 & 14 \\
\hline 1268 & 1248 & 650 & 3 & 1204 & 15 \\
\hline 972 & 942 & 660 & 4 & 1248 & 16 \\
\hline 1317 & 1367 & 760 & 5 & 1268 & 17 \\
\hline 760 & 766 & 766 & 6 & 1297 & 18 \\
\hline 1041 & 1052 & 845 & 7 & 1304 & 19 \\
\hline 1054 & 1106 & 911 & 8 & 1317 & 20 \\
\hline 650 & 648 & 942 & 9 & 1367 & 21 \\
\hline 911 & 845 & 972 & 10 & 1387 & 22 \\
\hline 1919 & 1930 & 1041 & 11 & 1919 & 23 \\
\hline 1304 & 1387 & 1052 & 12 & 1930 & 24 \\
\hline \multicolumn{5}{|c|}{ Sum of the ranks assigned to power output obtained from measured hourly wind speeds. } & 151 \\
\hline \multicolumn{5}{|c|}{ Sum of the ranks assigned to power output obtained from generated hourly wind speeds. } & 149 \\
\hline \multicolumn{5}{|c|}{ Critical value for the Wilcoxon Rank-Sum Test (5\% two-tail values) corresponding to samples of sizes 12 and 12 . } & 115 \\
\hline
\end{tabular}

Neither rank sum is less than (or equal to) the critical value.

Conclusion can be made basis on the available evidence, the null hypothesis at that $5 \%$ level of significance cannot be rejected. 


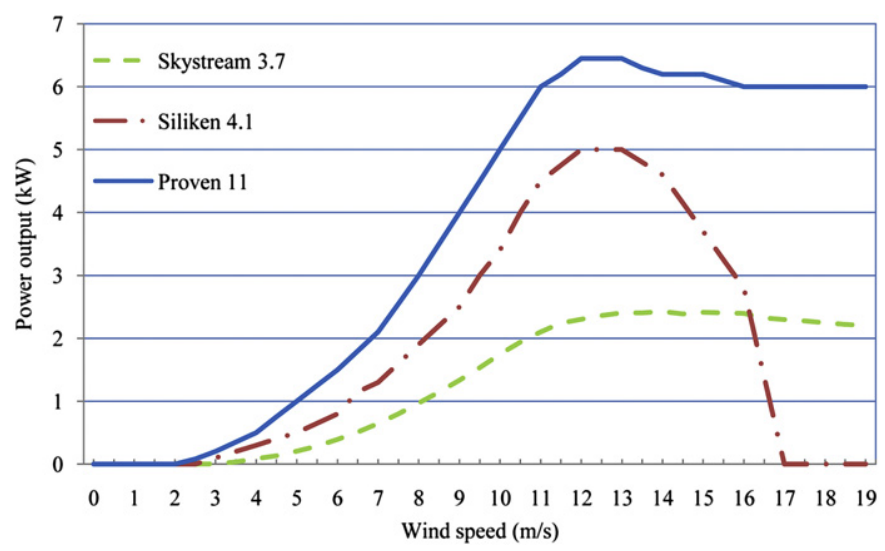

Fig. 8. Power curves for three micro wind turbines available on the Irish market [21-23].

\subsubsection{Validation of the wind speed algorithm}

The generated wind speed data from HOMER has to be validated in order to prove its accuracy. The validation is carried out using the Wilcoxon Rank-Sum Test which is a non-parametric statistical hypothesis test. The Proven 11 micro wind turbine and an annual average wind speed of $4.90 \mathrm{~m} / \mathrm{s}$ are used for this validation. The generated hourly wind speeds at $10 \mathrm{~m}$ height are obtained by applying the monthly average wind speed and all parameters stated above. The measured hourly wind speeds at $10 \mathrm{~m}$ height are obtained from Met Éireann, the Irish national meteorological service and the leading provider of weather information and related services for Ireland. Power outputs for 12 months from the Proven 11 turbine (detailed description in Section 4.3), are separately calculated using generated hourly wind speeds and measured hourly wind speeds. The 24 values are applied in the Wilcoxon Rank-Sum Test. The sums of rank for both power output from generated wind speeds and power output from measured wind speed are worked out and presented in Table 1 . The conclusion can be made based on the available evidence that the hourly wind speeds generated from HOMER are accurate and realistic, and they are appropriate for use in this study. The validation of wind speed algorithm from the Wilcoxon Rank-Sum Test is shown in Table 1.

\subsection{Determination of the power output from a micro wind turbine}

A micro wind turbine is characterised by its power curve. The power curve gives the power output, in kilowatts $(\mathrm{kW})$, for a given wind speed, in $\mathrm{m} / \mathrm{s}$, and takes into account all aspects including blade aerodynamics and auto-furling/stall effects, electrical generator, any gearing and the power electronics associated with turbine itself [3]. Fig. 8 shows the power curves for the Skystream 3.7, the Siliken 4.1 and the Proven 11 micro wind turbines. Three wind speeds on the power curve are used to describe the operation of a particular turbine, and are:

- Cut-in wind speed. This is the minimum wind speed that a wind turbine can generate usable power. Typically the cut-in wind speed is around $3 \mathrm{~m} / \mathrm{s}$ for micro wind turbines available in Ireland.

- Rated wind speed. This is the wind speed that a wind turbine can generate its rated power.

- Cut-out wind speed. This is the wind speed that a wind turbine ceases electricity generation and shuts down in order to prevent damage to itself. Typically the cut-out wind speed is $17 \mathrm{~m} / \mathrm{s}$ for the micro wind turbines available in Ireland. Most micro wind turbines are designed to prevent the blades rotating when the wind speed exceeds the cut-out speed. However, newly-designed micro wind turbines like the Proven 11 can regulate to their rated power and continuously generate power at high wind speeds.

The power output of a micro wind turbine for a specific hour can be obtained by applying the artificial wind speed generated by HOMER for this hour to the power curve. The same procedure is applied by HOMER for each corresponding hourly wind speed for a year. Hence, there are a total of 8760 hourly power outputs generated for a micro wind turbine. Every hourly power output of the micro wind turbine is then compared with the corresponding hourly electrical load. If the hourly power output exceeds the hourly electrical load, the power is used to satisfy the electrical demand in this hour, and the surplus power is exported to the grid. If the hourly power output is less than the hourly electrical load, the grid is used to supply the additional power to satisfy the electrical demand in the hour, and no power is exported.

\subsection{Calculation of the payback period}

The payback period is chosen to perform a comparative cost/ benefit analysis. The payback period, calculated in Microsoft Excel 2007, can be used to compare different micro wind turbines when they are installed in the same conditions. In the economic analysis, the assumption is made that the entire capital cost of a micro wind turbine (including the cost of installation) is funded from a loan. The annual repayment is calculated from the money saved by replacing the imported electricity and the profit made from the exported electricity to the grid. The standard formula for calculating the payback period is given by [24]:

$\mathrm{n}=\log (1+\mathrm{i})^{\left(1-\frac{\mathrm{i} * \mathrm{C}}{\mathrm{R}}\right)}$

where $\mathrm{n}$ is the payback period (number of years), $\mathrm{R}$ is the annual repayment on the loan, $C$ is the capital cost, and $i$ is the loan rate also called the annual percentage rate (APR).

Table 2

Relevant information for six micro wind turbines available on the Irish market in 2010 and selected for analysis in this study.

\begin{tabular}{|c|c|c|c|c|c|c|c|}
\hline Wind Turbine & $\begin{array}{l}\text { Rated Power } \\
(\mathrm{kW})\end{array}$ & $\begin{array}{l}\text { Cut-in Wind } \\
\text { Speed }(\mathrm{m} / \mathrm{s})\end{array}$ & $\begin{array}{l}\text { Cut-out Wind } \\
\text { Speed }(\mathrm{m} / \mathrm{s})\end{array}$ & $\begin{array}{l}\text { Hub } \\
\text { Height (m) }\end{array}$ & $\begin{array}{l}\text { Capital } \\
\text { Cost (Euro) }\end{array}$ & $\begin{array}{l}\text { O\&M}^{\mathrm{a}} \text { Costs } \\
\text { (Euro/year) }\end{array}$ & $\begin{array}{l}\text { Lifespan } \\
\text { (Years) }\end{array}$ \\
\hline Ampair 600-230[25] & 0.6 & 3 & none & 10 & 4800 & 50 & 15 \\
\hline Swift 1.5 kW[26] & 1.5 & 3.5 & 22 & 11 & 7000 & 50 & 20 \\
\hline Skystream 3.7[21] & 2.4 & 3.5 & 25 & 14 & 12,363 & 100 & 20 \\
\hline Siliken $3.4[22]$ & 3.8 & 3.5 & 17 & 11 & 15,995 & 150 & 20 \\
\hline Siliken $4.1[22]$ & 5 & 3.5 & 17 & 11 & 19,995 & 150 & 20 \\
\hline Proven 11[23] & 6 & 2.5 & none & 15 & 30,000 & 150 & 25 \\
\hline
\end{tabular}

${ }^{\mathrm{a}}$ O\&M- Operation and Maintenance. 


\section{Analysis of the economic viability of installing a micro wind turbine in Ireland}

The methodology just described is applied to analyse the economic viability of six micro wind turbines available in Ireland. The selected micro wind turbines analysed in this study cover a wide range of suppliers and rated power specifications. They are the Ampair 600-230, the Swift $1.5 \mathrm{~kW}$, the Skystream 3.7, the Siliken 3.4, the Siliken 4.1 and the Proven 11. Table 2 gives relevant information for each of these micro wind turbines. This indicative information was obtained from either official company websites or from personal communications [21-23,25,26]. The analysis of economic viability of installing these micro wind turbines in Ireland is subjected to the following conditions:

- Three wind speeds are used: $5.67 \mathrm{~m} / \mathrm{s}, 4.90 \mathrm{~m} / \mathrm{s}$ and $6.06 \mathrm{~m} / \mathrm{s}$. These three wind speeds were the annual average wind speeds at Dublin Airport, Cork Airport and Belmullet respectively in 2009 [27]. The monthly average wind speeds available for these locations shows the seasonal variation for a year. Fig. 9 shows the annual average wind speed at $10 \mathrm{~m}$ height in Ireland.

- A green loan having a loan rate of $4.5 \%$, offered by St Patrick's Credit Union in Ireland, is used in this study. All payback periods are calculated based on this loan rate unless it is stated differently.

- The annual average household electricity load of $5557 \mathrm{kWh}$ is used in this study. All payback periods are calculated based on this annual household electricity load unless it is stated differently.

- An imported electricity price of $€ 0.16 / \mathrm{kWh}$ is used for calculating the payback period.

- An exported electricity price of $€ 0.09 / \mathrm{kWh}$ is used for calculating the payback period. The incentive exported electricity price $(€ 0.19 / \mathrm{kWh})$ is utilised for a maximum of $3000 \mathrm{kWh}$ a year, and for the first five years from the beginning of electricity export to the grid.

\subsection{Payback period under the current Irish conditions}

The payback periods for the six sample micro wind turbines have been worked out under Ireland's current conditions, including

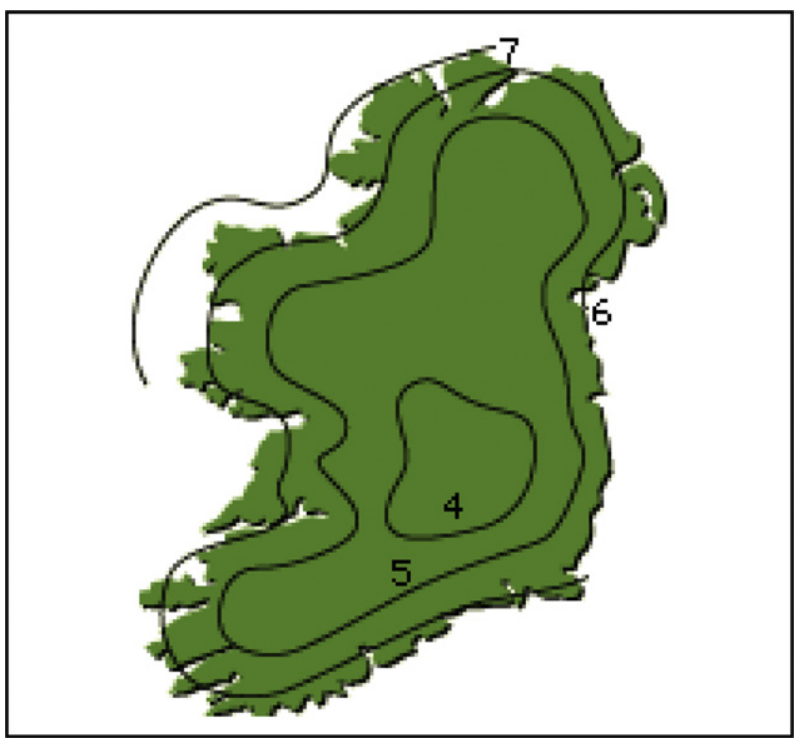

Fig. 9. Annual average wind speed $(\mathrm{m} / \mathrm{s})$ in Ireland in 2010 [28].
Table 3

Payback period (in years) for six sample micro wind turbines for three annual average wind speeds. Loan rate is $4.5 \%$, imported electricity price is $€ 0.16 / \mathrm{kWh}$, exported electricity price is $€ 0.09 / \mathrm{kWh}$ and incentive exported electricity price is $€ 0.19 / \mathrm{kWh}$.

\begin{tabular}{llll}
\hline Wind Turbine & $4.90 \mathrm{~m} / \mathrm{s}$ & $5.67 \mathrm{~m} / \mathrm{s}$ & $6.06 \mathrm{~m} / \mathrm{s}$ \\
\hline Ampair 600-230 & $\infty^{\mathrm{a}}$ & $\infty$ & 58.9 \\
Swift 1.5 kW & $\infty$ & $\infty$ & $\infty$ \\
Skystream 3.7 & $\infty$ & 35.6 & 25.3 \\
Siliken 3.4 & $\infty$ & 39.9 & 28.5 \\
Siliken 4.1 & $\infty$ & 33.5 & 25.5 \\
Proven 11 & 51.3 & 26.2 & 21.6 \\
\hline
\end{tabular}

a $\infty$ means the micro wind turbine cannot pay back under the scenario stated.

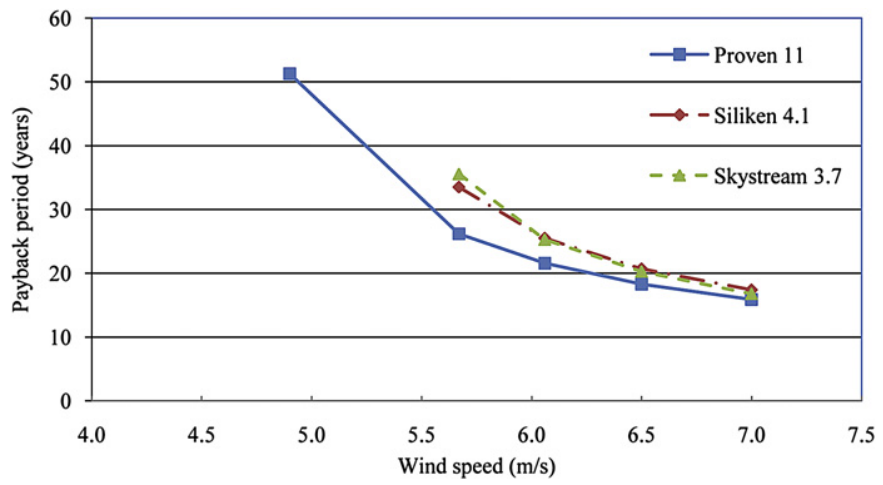

Fig. 10. Payback period (in years) for three sample micro wind turbines for different annual average wind speeds. Loan rate is $4.5 \%$, imported electricity price is $€ 0.16 / \mathrm{kWh}$, exported electricity price is $€ 0.09 / \mathrm{kWh}$ and incentive exported electricity price is $€ 0.19 / \mathrm{kWh}$.

average household electrical load, imported electricity price, exported electricity price and loan rate.

Table 3 shows that the sample micro wind turbines cannot payback or have very long payback periods under the current Irish conditions. Most of the turbines cannot payback in their lifespan, especially at a location having low annual average wind speed. A micro wind turbine may be considered not to be economically viable at low wind speed locations in Ireland $(<5 \mathrm{~m} / \mathrm{s})$. However, a micro wind turbine looks promising when it is installed in locations having high annual average wind speeds ( $>6 \mathrm{~m} / \mathrm{s}$ ); indeed the payback period can be shorter than the turbine's lifespan. Fig. 10 shows the effect of wind speed on payback period for three sample micro wind turbines. At the same location, the larger capacity micro wind turbines are more likely to be economically viable in comparison with smaller capacity micro wind turbines.

Table 4

Payback period (in years) for six sample micro wind turbines for three annual average wind speeds and for three electrical loads. Loan rate is $4.5 \%$, imported electricity price is $€ 0.16 / \mathrm{kWh}$, exported electricity price is $€ 0.09 / \mathrm{kWh}$ and incentive exported electricity price is $€ 0.19 / \mathrm{kWh}$.

\begin{tabular}{llllllllllll}
\hline \multirow{2}{*}{ Wind Turbine } & \multicolumn{3}{l}{$4.90 \mathrm{~m} / \mathrm{s}$} & \multicolumn{3}{l}{$5.67 \mathrm{~m} / \mathrm{s}$} & \multicolumn{3}{l}{$6.06 \mathrm{~m} / \mathrm{s}$} \\
\cline { 2 - 10 } & \multicolumn{1}{l}{ Household Electrical Load $(\mathrm{kWh})$} \\
\cline { 2 - 10 } & 4500 & 6500 & 8000 & 4500 & 6500 & 8000 & 4500 & 6500 & 8000 \\
\hline Ampair 600-230 & $\infty$ & $\infty$ & $\infty$ & $\infty$ & $\infty$ & $\infty$ & 65.6 & 56.3 & 54.1 \\
Swift 1.5 kW & $\infty$ & $\infty$ & $\infty$ & $\infty$ & $\infty$ & $\infty$ & $\infty$ & 104.6 & 77.8 \\
Skystream 3.7 & $\infty$ & $\infty$ & $\infty$ & 38.5 & 33.8 & 31.6 & 27.5 & 24.4 & 23.2 \\
Siliken 3.4 & $\infty$ & $\infty$ & $\infty$ & 45.2 & 36.8 & 33.4 & 30.9 & 26.8 & 24.8 \\
Siliken 4.1 & $\infty$ & $\infty$ & $\infty$ & 36.7 & 31.4 & 28.8 & 27.3 & 24.3 & 22.6 \\
Proven 11 & 59.6 & 46.5 & 41.2 & 27.7 & 25.0 & 23.5 & 22.6 & 20.8 & 19.7 \\
\hline
\end{tabular}




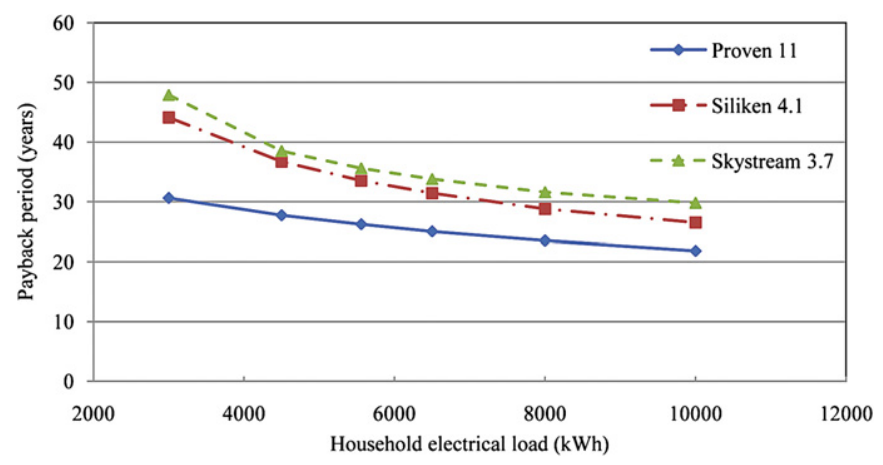

Fig. 11. Payback period (in years) versus household electrical load for the Proven 11 the Siliken 4.1 and the Skystream 3.7 micro wind turbines for an annual average wind speed of $5.67 \mathrm{~m} / \mathrm{s}$. Loan rate is $4.5 \%$, imported electricity price is $€ 0.16 / \mathrm{kWh}$, exported electricity price is $€ 0.09 / \mathrm{kWh}$ and the incentive exported electricity price is $€ 0.19 /$ kWh.

\subsection{The effect of household electrical load on the payback period}

The annual household electrical load depends on the number of occupants and the usage of electrical appliances in the house. The electricity generated from a micro wind turbine is more likely to be used entirely for the house if the household electrical load is high. Therefore, very little generated electricity is left to export to ESB Networks. On the other hand, there can be quite a lot of generated electricity to export if the household electrical load is low. This change of household electricity consumption will affect the payback period of a micro wind turbine.

Table 4 shows that the payback period becomes shorter as the household electrical load increases as the majority of electricity generated is being utilised in the house rather than exported to ESB Networks. Therefore, the difference between the current imported electricity price and the exported electricity price makes the micro wind turbine more likely to be economically viable when it is installed in a house having a high electrical load. Fig. 11 shows the effect of household electrical load on the payback period for the Proven 11, the Siliken 4.1 and the Skystream 3.7 micro wind turbines.

\subsection{The effect of imported electricity price on payback period}

Imported electricity price is another factor affecting the payback period of micro wind turbines. Electricity generation is mainly dependent on imported fossil fuels (natural gas and coal) in Ireland.

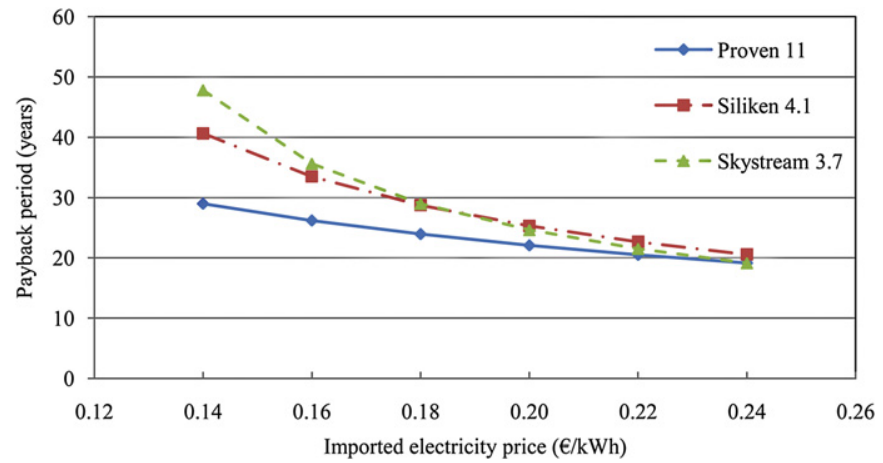

Fig. 12. Payback period (in years) versus imported electricity price for the Proven 11 , the Siliken 4.1 and the Skystream 3.7 micro wind turbines for an annual average wind speed of $5.67 \mathrm{~m} / \mathrm{s}$. Loan rate is $4.5 \%$, exported electricity price is $€ 0.09 / \mathrm{kWh}$ and incentive exported electricity price is $€ 0.19 / \mathrm{kWh}$.

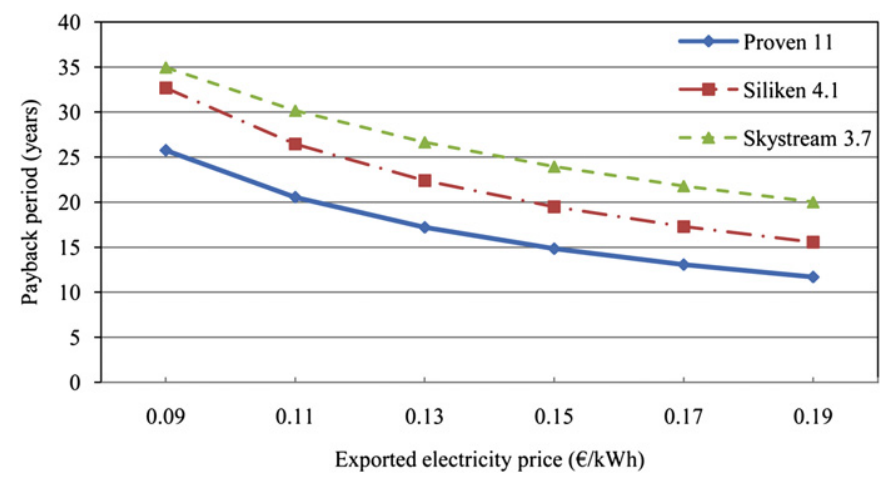

Fig. 13. Payback period (in years) versus exported electricity price for three micro wind turbines for an annual average wind speed of $5.67 \mathrm{~m} / \mathrm{s}$. Loan rate is $4.5 \%$ imported electricity price is $€ 0.16 / \mathrm{kWh}$ and the added incentive exported electricity price is $€ 0.10 / \mathrm{kWh}$.

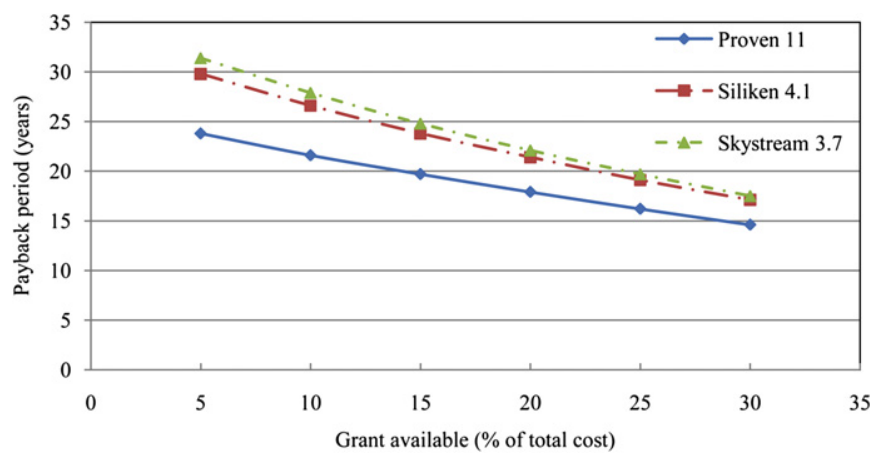

Fig. 14. Payback period (in years) versus the capital grant available for three micro wind turbines for an annual average wind speed of $5.67 \mathrm{~m} / \mathrm{s}$. Loan rate is $4.5 \%$, imported electricity price is $€ 0.16 / \mathrm{kWh}$, exported electricity price is $€ 0.09 / \mathrm{kWh}$ and incentive exported electricity price is $€ 0.19 / \mathrm{kWh}$.

Fossil fuel prices are expected to rise in the coming years as there is less fossil fuel available globally. Electricity prices will increase along with the fossil fuel price rises. Installing a micro wind turbine may gradually show its economic viability as the electricity generated from the micro wind turbine can replace part of or the entire electricity consumed in a house.

Table 5 shows that the length of the payback period of a micro wind turbine will decrease significantly as the imported electricity price rises. Some of the micro wind turbines may become

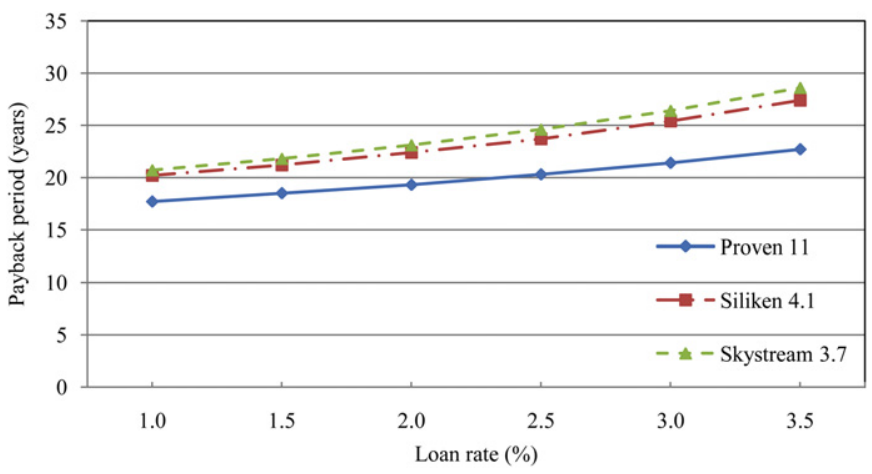

Fig. 15. Payback period (in years) versus loan rate for the Proven 11, the Siliken 4.1 and the Skystream 3.7 micro wind turbines for an annual average wind speed of $5.67 \mathrm{~m} / \mathrm{s}$ Loan rate is $4.5 \%$, imported electricity price is $€ 0.16 / \mathrm{kWh}$, exported electricity price is $€ 0.09 / \mathrm{kWh}$ and incentive exported electricity price is $€ 0.19 / \mathrm{kWh}$. 
Table 5

The payback period (in years) for six sample micro wind turbines for three annual average wind speeds and for three imported electricity prices. Loan rate is $4.5 \%$, exported electricity price is $€ 0.09 / \mathrm{kWh}$ and incentive exported electricity price is $€ 0.19 / \mathrm{kWh}$.

\begin{tabular}{llllllllllll}
\hline Wind Turbine & \multicolumn{3}{l}{$4.90 \mathrm{~m} / \mathrm{s}$} & \multicolumn{3}{l}{$5.67 \mathrm{~m} / \mathrm{s}$} & \multicolumn{1}{l}{$6.06 \mathrm{~m} / \mathrm{s}$} \\
\cline { 2 - 10 } & \multicolumn{1}{l}{ Imported Electricity Price $(€ / \mathrm{kWh})$} \\
\cline { 2 - 10 } & 0.15 & 0.18 & 0.21 & 0.15 & 0.18 & 0.21 & 0.15 & 0.18 & 0.21 \\
\hline Ampair 600-230 & $\infty$ & $\infty$ & $\infty$ & $\infty$ & 63.3 & 34.5 & $\infty$ & 40.9 & 27.2 \\
Swift 1.5 kW & $\infty$ & $\infty$ & $\infty$ & $\infty$ & $\infty$ & 74.3 & $\infty$ & 58.2 & 35.3 \\
Skystream 3.7 & $\infty$ & $\infty$ & 57.2 & 43.8 & 30.4 & 23.8 & 28.9 & 22.5 & 18.5 \\
Siliken 3.4 & $\infty$ & $\infty$ & 83.5 & 49.8 & 33.9 & 26.5 & 32.6 & 25.4 & 21.0 \\
Siliken 4.1 & $\infty$ & $\infty$ & 50.9 & 38.5 & 29.8 & 24.6 & 28.2 & 23.4 & 20.1 \\
Proven 11 & 63.6 & 44.1 & 35.1 & 28.2 & 24.5 & 21.7 & 22.9 & 20.4 & 18.5 \\
\hline
\end{tabular}

economically viable when the imported electricity price has reached a certain point in the future. There could also be other forms of electricity price increases, including the adjustment of VAT and/or a levy charge on the usage of electricity. These could all influence the payback period of a micro wind turbine utilised for a house. Fig. 12 shows the effect of imported electricity price on the payback period of the Proven 11, the Siliken 4.1 and Skystream 3.7 micro wind turbines.

\subsection{The effect of exported electricity price on payback period}

The electricity generated by the micro wind turbine may exceed the household electrical load required, as typically occurs during the night. Previously, the surplus electricity generated was fed back to the grid for free in Ireland. The introduced exported electricity tariff has been a great incentive for householder having a micro wind turbine installed. The extra financial income obtained other than from savings made by replacing electricity consumed in the house can certainly help to reduce the payback period of a micro wind turbine.

Table 6 shows the extra $€ 0.03, € 0.06$ and $€ 0.09$ offered for per $\mathrm{kWh}$ of exported electricity can have a significant impact on the payback period of a micro wind turbine. The payback period of some micro wind turbines can be reduced by over 10 years compared with the current exported electricity price offered. A number of micro wind turbines would become genuinely economically viable if a higher exported electricity price was offered by the Irish electricity suppliers. Fig. 13 shows the effect of exported electricity price on the payback period for the Proven 11, the Siliken 4.1 and the Skystream 3.7 micro wind turbines.

\subsection{The effect of a capital grant on payback period}

A capital grant is a key incentive for all the householders who are interested in installing a micro renewable energy system. There

Table 6

Payback periods (in years) for six sample micro wind turbines for three annual average wind speeds and for three exported electricity prices. Loan rate is $4.5 \%$, imported electricity price is $€ 0.16 / \mathrm{kWh}$ and the added incentive exported electricity price is $€ 0.10 / \mathrm{kWh}$.

\begin{tabular}{lllllllllll}
\hline Wind Turbine & \multicolumn{3}{l}{$4.90 \mathrm{~m} / \mathrm{s}$} & \multicolumn{3}{l}{$5.67 \mathrm{~m} / \mathrm{s}$} & \multicolumn{7}{l}{$6.06 \mathrm{~m} / \mathrm{s}$} \\
\cline { 2 - 10 } & \multicolumn{3}{l}{ Exported Electricity Price $(€ / \mathrm{kWh})$} \\
\cline { 2 - 11 } & 0.12 & 0.15 & 0.18 & 0.12 & 0.15 & 0.18 & 0.12 & 0.15 & 0.18 \\
\hline Ampair 600-230 & $\infty$ & $\infty$ & $\infty$ & $\infty$ & $\infty$ & $\infty$ & 54.5 & 50.9 & 47.9 \\
Swift 1.5 kW & $\infty$ & $\infty$ & $\infty$ & $\infty$ & $\infty$ & $\infty$ & 71.9 & 55.1 & 46.3 \\
Skystream 3.7 & $\infty$ & 101.5 & 57.1 & 27.9 & 23.2 & 19.9 & 20.5 & 17.4 & 15.1 \\
Siliken 3.4 & $\infty$ & 78.3 & 47.9 & 28.8 & 22.9 & 19.2 & 21.7 & 17.6 & 14.9 \\
Siliken 4.1 & 61.1 & 39.3 & 30.3 & 24.2 & 19.2 & 16.0 & 19.1 & 15.4 & 12.9 \\
Proven 11 & 31.2 & 23.3 & 18.8 & 18.8 & 14.8 & 12.2 & 15.8 & 12.5 & 10.4 \\
\hline
\end{tabular}

is currently no grant available for micro wind turbines in Ireland. However, the high capital cost is one of the most significant barriers that prevents a householder installing a micro wind turbine. Sustainable Energy Authority Ireland (SEAI) is Ireland's national energy authority. Grants offered from SEAI have significantly increased the number of installed domestic renewable technologies such as heat pumps, solar thermal systems and biomass boilers; however, there is no capital grant available for domestic micro wind turbines to-date (November 2010). If appropriate financial support can be made available by SEAI or other Irish government bodies, micro wind turbines will become an attractive renewable technology option in Ireland.

Table 7 shows the payback period of a micro wind turbine will be significantly shortened by providing a grant worth $5 \%, 10 \%$ and $20 \%$ of capital costs. The grant available can genuinely make the installation of some micro wind turbines economically viable. The funding of capital grants for micro wind turbines is very large, and it may not be realistic for SEAI or other Irish government bodies to provide under the current difficult economic conditions. However, if funding can be generated and offered to the householders, it will be an effective additional support to develop the micro wind turbine installation in Ireland. Fig. 14 shows the change of payback period for the Proven 11, the Siliken 4.1 and the Skystream 3.7 micro wind turbines with various percentages of capital grants available.

\subsection{The effect of loan rate on the payback period}

The purchase of a micro wind turbine is a big investment for most householders. Hence, the repayment loan rate can act to be a decisive factor for the payback period of a micro wind turbine. The introduced green loans have shown the interest in renewable energy technologies from many banks and credit unions in Ireland. The green loan rate, offered from the banks and credit unions, is typically between $1 \%$ and $2 \%$ less than the current personal loan rate. Bank of Ireland offers a green loan rate of $11.9 \%$ and Ulster Bank offers a green loan rate of $10.5 \%$. However, this green loan rate, is available for purchasing micro wind turbine, is still considered to be too high to help develop the micro wind turbine market in Ireland.

Table 8 shows that the loan rate can be a decisive factor if a micro wind turbine is to be economically viable. At the loan rate of $1 \%$, some micro wind turbines will have a chance to pay themselves back during their lifespan even in the locations having low average wind speed $(<5 \mathrm{~m} / \mathrm{s})$. Nearly all micro wind turbines are possible to payback in their lifespan using the same loan rate in the locations having high average wind speed ( $>6 \mathrm{~m} / \mathrm{s}$ ). However, once the loan rate rises up to 5\%, most wind turbines cannot pay back at the low wind speed locations. None of micro wind turbines can pay back in their lifespan when the loan rate reaches $10 \%$, even if they are

Table 7

Payback period (in years) for six sample micro wind turbines for three annual average wind speeds and for three capital grants. Loan rate is $4.5 \%$, imported electricity price is $€ 0.16 / \mathrm{kWh}$, exported electricity price is $€ 0.09 / \mathrm{kWh}$ and incentive exported electricity price is $€ 0.19 / \mathrm{kWh}$.

\begin{tabular}{lllllllllll}
\hline Wind Turbine & \multicolumn{3}{l}{$4.90 \mathrm{~m} / \mathrm{s}$} & \multicolumn{3}{l}{$5.67 \mathrm{~m} / \mathrm{s}$} & \multicolumn{5}{c}{$6.06 \mathrm{~m} / \mathrm{s}$} \\
\cline { 2 - 11 } & \multicolumn{1}{l}{ Capital Grant (\% of total cost) } \\
\cline { 2 - 11 } & 5 & 10 & 20 & 5 & 10 & 20 & 5 & 10 & 20 \\
\hline Ampair 600-230 & $\infty$ & $\infty$ & $\infty$ & 109.9 & 64.0 & 41.2 & 48.1 & 40.7 & 30.7 \\
Swift 1.5 kW & $\infty$ & $\infty$ & $\infty$ & $\infty$ & $\infty$ & 146.2 & 72.0 & 53.9 & 37.0 \\
Skystream 3.7 & $\infty$ & $\infty$ & 58.7 & 31.4 & 27.9 & 22.1 & 22.9 & 24.6 & 16.9 \\
Siliken 3.4 & $\infty$ & $\infty$ & 74.3 & 34.8 & 30.5 & 23.9 & 25.6 & 23.1 & 18.8 \\
Siliken 4.1 & $\infty$ & 74.6 & 42.9 & 29.8 & 26.6 & 21.4 & 23.2 & 21.1 & 17.3 \\
Proven 11 & 43.1 & 36.9 & 28.3 & 23.8 & 21.6 & 17.8 & 19.8 & 18.2 & 15.2 \\
\hline
\end{tabular}


Table 8

Payback period (in years) for six sample micro wind turbines for three annual average wind speeds and for three loan rates. Imported electricity price is $€ 0.16$ / $\mathrm{kWh}$, exported electricity price is $€ 0.09 / \mathrm{kWh}$ and incentive exported electricity price is $€ 0.19 / \mathrm{kWh}$

\begin{tabular}{lllllllllll}
\hline Wind Turbine & \multicolumn{3}{l}{$4.90 \mathrm{~m} / \mathrm{s}$} & \multicolumn{3}{l}{$5.67 \mathrm{~m} / \mathrm{s}$} & \multicolumn{7}{l}{$6.06 \mathrm{~m} / \mathrm{s}$} \\
\cline { 2 - 11 } & \multicolumn{1}{l}{ Loan Rate (\%) } & & & & & & & \\
\cline { 2 - 11 } & 1 & 5 & 10 & 1 & 5 & 10 & 1 & 5 & 10 \\
\hline Ampair 600-230 & 45.8 & $\infty$ & $\infty$ & 28.7 & $\infty$ & $\infty$ & 25.0 & $\infty$ & $\infty$ \\
Swift 1.5 kW & 72.6 & $\infty$ & $\infty$ & 35.6 & $\infty$ & $\infty$ & 27.6 & $\infty$ & $\infty$ \\
Skystream 3.7 & 32.6 & $\infty$ & $\infty$ & 20.7 & 42.2 & $\infty$ & 17.2 & 27.6 & $\infty$ \\
Siliken 3.4 & 34.3 & $\infty$ & $\infty$ & 21.8 & 49.8 & $\infty$ & 18.5 & 31.8 & $\infty$ \\
Siliken 4.1 & 29.6 & $\infty$ & $\infty$ & 20.2 & 38.8 & $\infty$ & 17.4 & 27.9 & $\infty$ \\
Proven 11 & 24.0 & 87.6 & $\infty$ & 17.7 & 28.7 & $\infty$ & 15.7 & 23.1 & $\infty$ \\
\hline
\end{tabular}

installed in high average wind speed locations. Unfortunately, the current loan rates from banks and credit union are considered to be too high to make micro wind turbines installation economically viable in Ireland. Fig. 15 shows the effect of loan rate on the payback period for the Proven 11, the Siliken 4.1 and the Skystream 3.7 micro wind turbines.

\subsection{The effect of the number of incentive years on the payback period}

The added $€ 0.10 / \mathrm{kWh}$ incentive exported electricity tariff (restricted to less than $3000 \mathrm{kWh}$ ) is currently valid for five years from the contract start with ESB Networks for an installed micro wind turbine. Increasing the number of incentive years can affect the payback period as shown here.

Table 9 shows the additional incentive years can make a significant difference in payback period for micro wind turbines installed at the location with middle average wind speed $(5 \mathrm{~m} / \mathrm{s}-6 \mathrm{~m} / \mathrm{s})$. Some micro wind turbines can become economically viable or near economically viable after the extra incentive years have been offered. However, the extra incentive years will not have any significant impact on the micro wind turbines located in the areas having relatively high average wind speed $(>6 \mathrm{~m} / \mathrm{s})$.

\subsection{The effect of a carbon tax on payback period}

The possible future introduction of a carbon tax is taken into consideration in this case. Even though there is no current carbon tax imposed on electricity generation, domestic heating has been affected by the introduction of a carbon tax since 1st of May 2010 in Ireland [29]. A carbon tax may soon be introduced on electricity generation, as electricity generation is one of the largest carbon dioxide emitters along with transportation in Ireland [1]. The penalty rate used is $€ 15$ per tonne of carbon dioxide emitted. The

\section{Table 9}

Payback period (in years) for six sample micro wind turbines for three annual average wind speeds and for three incentive-year lengths. Loan rate is $4.5 \%$, imported electricity price is $€ 0.16 / \mathrm{kWh}$, exported electricity price is $€ 0.09 / \mathrm{kWh}$ and the incentive exported electricity price is $€ 0.19 / \mathrm{kWh}$.

\begin{tabular}{lllllllllll}
\hline Wind Turbine & \multicolumn{3}{l}{$4.90 \mathrm{~m} / \mathrm{s}$} & \multicolumn{3}{l}{$5.67 \mathrm{~m} / \mathrm{s}$} & \multicolumn{5}{l}{$6.06 \mathrm{~m} / \mathrm{s}$} \\
\cline { 2 - 11 } & \multicolumn{3}{l}{ Number of Incentive Years } \\
\cline { 2 - 11 } & 5 & 10 & 15 & 5 & 10 & 15 & 5 & 10 & 15 \\
\hline Ampair 600-230 & $\infty$ & $\infty$ & $\infty$ & $\infty$ & 84.8 & 63.3 & 58.9 & 46.2 & 41.9 \\
Swift 1.5 kW & $\infty$ & $\infty$ & $\infty$ & $\infty$ & $\infty$ & $\infty$ & $\infty$ & 59.8 & 48.8 \\
Skystream 3.7 & $\infty$ & $\infty$ & 91.7 & 35.6 & 27.7 & 24.8 & 25.3 & 20.4 & 18.8 \\
Siliken 3.4 & $\infty$ & $\infty$ & 127.9 & 39.9 & 30.3 & 26.8 & 28.5 & 23.3 & 21.6 \\
Siliken 4.1 & $\infty$ & 71.4 & 49.6 & 33.5 & 27.4 & 25.2 & 25.5 & 21.9 & 20.9 \\
Proven 11 & 51.3 & 38.9 & 34.8 & 26.2 & 23.1 & 22.4 & 21.6 & 19.6 & 19.5 \\
\hline
\end{tabular}

\section{Table 10}

Payback period (in years) for six sample micro wind turbines for three annual average wind speeds with a carbon tax introduced. Loan rate is $4.5 \%$, imported electricity price is $€ 0.16 / \mathrm{kWh}$, exported electricity price is $€ 0.09 / \mathrm{kWh}$ and the incentive exported electricity price is $€ 0.19 / \mathrm{kWh}$.

\begin{tabular}{llll}
\hline Wind Turbine & $4.90 \mathrm{~m} / \mathrm{s}$ & $5.67 \mathrm{~m} / \mathrm{s}$ & $6.06 \mathrm{~m} / \mathrm{s}$ \\
\hline Ampair 600-230 & $\infty$ & 88.5 & 46.4 \\
Swift $1.5 \mathrm{~kW}$ & $\infty$ & $\infty$ & 71.5 \\
Skystream 3.7 & $\infty$ & 32.3 & 23.6 \\
Siliken 3.4 & $\infty$ & 36.2 & 26.6 \\
Siliken 4.1 & $\infty$ & 31.2 & 24.2 \\
Proven 11 & 46.7 & 45.2 & 20.9 \\
\hline
\end{tabular}

carbon dioxide emissions were $582 \mathrm{~g}$ for every kWh electricity generated in Ireland in 2008, and this value is used in this study.

Table 10 shows that the introduction of a carbon tax could slightly shorten the payback period of the micro wind turbines. Depending on the amount of electricity consumed in the house that is replaced by electricity generated from a micro wind turbine, the householder could avoid up to $€ 70$ of a carbon tax a year.

\section{Conclusion}

The economic viability of six sample micro wind turbines for use in Ireland has been investigated in this paper. The computer programme HOMER and economic calculation are used to examine variations in economical viability due to variations in climate conditions and financial incentives associated with a specific micro wind turbine installation. This ensures a relatively accurate analysis to perform for a specific location, under current technical and cost conditions [30]. The paper's purpose is not to give a definitive answer with regard to the economic viability of micro wind turbines in Ireland. However, some broad conclusions regarding with economical viability of micro wind turbines for Irish application are made. The micro wind turbine is currently not economically viable if it is installed in locations with relatively low average wind speed $(<5 \mathrm{~m} / \mathrm{s})$. However, micro wind turbine looks more promising when it is installed in locations with relative high wind speed $(>6 \mathrm{~m} / \mathrm{s})$. There are seven appropriate assumptions made in the paper. These assumptions have covered most of the scenarios which will influence the future penetration of micro wind turbines in Ireland. From this study, results show that all of micro wind turbines will be economically viable in Ireland once they are subjected to a practical condition. Providing lower loan rates and/or substantial capital grants are the best incentive approaches to encourage maximum penetration of micro wind turbines. Government supports have proven to be extremely important in the penetration of micro wind turbines in Ireland. Even though the micro wind generation has yet to become popular in Ireland due to the high capital cost and long payback period for a micro wind turbine, the Irish government has made enormous effort to develop the micro wind generation market by offering financial supports, even during the current recession period. The popularity of micro wind turbine installation will certainly be increased if a substantial financial assistance can be made available once the Irish economy is recovered.

Ultimately, each householder should always make a decision in their individual case if a micro wind turbine is worthwhile to be installed, taking into consideration the local climate condition, the micro wind turbines available to them and the financial incentives for micro wind generation. In addition to this, the micro wind turbine market is dynamic, continuously influenced by improvements in micro wind turbine technology, the economies of scale in production and the change in Irish government policy towards micro wind turbine installations. The economic analysis described 
in this paper can be used by householders to determine the viability of micro wind turbine installation in their case.

\section{Acknowledgement}

The first author would like to express his appreciation to the Irish Research Council for Science, Engineering and Technology for its support during the research study period.

\section{References}

[1] O'Rourke F, Boyle F, Reynolds A. Renewable energy resources and technologies applicable to Ireland. Renewable and Sustainable Energy Reviews 2009; 13(8):1975-84.

[2] Dennehy E, Howley M, Ó Gallachóir B, Barriscale A. Renewable energy in Ireland 2010 update. Sustainable Energy Authority Ireland; 2010.

[3] Kelleher J, Ringwood JV. A computational tool for evaluating the economics of solar and wind microgeneration of electricity. Energy 2009;34(4):401-9.

[4] Howley M, Ó Gallachóir B, O'Leary F. Energy in the residential sector Sustainable Energy Authority Ireland; 2008.

[5] Your guide to electricity in the home. Sustainable Energy Authority Ireland; 2009.

[6] Factsheet: competition in electricity supply. 2010.

[7] Howley M, Ó Gallachóir B. Electricity \& gas prices in Ireland annex - household electricity prices. Sustainable Energy Authority Ireland; 2010

[8] McCarthy M. ESBN NC6 Stats. Sustainable Energy Authority Ireland; 2010.

[9] Puissance W. Ampair 600 [cited 15.10.10]; Available from: http://www.wattet-puissance.com/rubrique,eolienne-horizontale-1,347878.html; 2009.

[10] Treehugger, Swift rooftop wind system. 2009.

[11] Expo, A. Skystream 3.7.09.

[12] Siliken wind turbine. 2009; Siliken.

[13] Greenlight Electric company. Renewable energy systems. 2009.
[14] Statutory instruments -- planning and development regulations 2007. Department of Environment, Heritage and Local Government; 2007.

[15] Micro generation domestic payment scheme. ESB Customer Supply; 2009.

[16] Hamad AA, Alsaad MA. A software application for energy flow simulation of a grid connected photovoltaic system. Energy Conversion and Management 2010;51(8):1684-9.

[17] Khan MJ, Iqbal MT. Pre-feasibility study of stand-alone hybrid energy systems for applications in Newfoundland. Renewable Energy 2005;30(6): 835-54.

[18] Dennehy E, Howley M, Ó Gallachóir B. Energy in Ireland 1990-2008. Sustainable Energy Authority Ireland; 2009.

[19] Standard load profiles 2009. 2010; Retail Market Design Service.

[20] Seguro JV, Lambert TW. Modern estimation of the parameters of the Weibull wind speed distribution for wind energy analysis. Journal of Wind Engineering and Industrial Aerodynamics 2000;85(1):75-84.

[21] The price and technical data of skystream 3.7. Southwest Windpower; 2010.

[22] The price list and technical data of Siliken 3.4 and Siliken 4.1 micro wind turbines, Siliken Wind.

[23] Proven energy - products [cited 1809 2010]; Available from: http://www. provenenergy.co.uk/our-products/; 2009.

[24] Malik A, Al-Badi AH. Economics of wind turbine as an energy fuel saver - A case study for remote application in Oman. Energy 2009;34(10):1573-8.

[25] AMPAIR 600 wind generator \& accessories price600 wind generator \& accessories [cited 22.09.10]; Available from: http://www.boost-energy.com/ UserFiles/Downloads/CD_3001_Ampair_Price_List_(rev_1_3,_25_Apr_2010). pdf; 2010 .

[26] Swift rooftop wind energy system (swift) - frequently asked questions. Cascade Renewable Energy; 2007.

[27] Average monthly wind speed data 2009, from 01.01.09 to 31.12.09. Met Eireann; 2010.

[28] Average wind speed in Ireland. Met Eireann; 2010.

[29] Summary of 2010 budget measures policy changes. Department of Finance Ireland; 2009.

[30] Dalton GJ, Lockington DA, Baldock TE. Case study feasibility analysis of renewable energy supply options for small to medium-sized tourist accommodations. Renewable Energy 2009;34(4):1134-44. 